\title{
Investigation of the Effects of Group Research Method of Applying Modeling Based Teaching Method in the Particle Structure and Properties of Matter Unit on Constructivist Learning*
}

\author{
Yusuf ZORLU $^{* *} \quad$ Fatih SEZEK $^{* * *}$
}

\begin{abstract}
The aim of this study was investigated of the effects of Grup Investigation (GI) method of applying Modeling Based Teaching (MBT) method in the "The Particle Structure and Properties of Matter" unit on constructivist learning. It was used pretest-posttest quasi-experimental design. This research was selected two groups of seventh graders in a middle school. The first group (EG1) was applied the GI method and the second group (EG2) was applied the GI and the MBT methods together. The data were collected using the Constructivist Learning Environment Scale (CLES) and focus group interviews. The results of the CLES indicated the MBT method was contributed in the factors of "Discussions and Interviews", "Conceptual Discrepancies", "Sharing Views with Others", "Reflection and Motivation for Discovering Concepts" and "Meeting the Needs of Learners" on the GI method. In the focus group interviews, the students applied modeling Based Teaching (MBT) and Grup Investigation (GI) methods together articulated to improving mental perspectives, having confused thoughts, learning to question the things learned so far and learning to use the knowledge learned so far. The students stated that they experienced having confused thoughts during the application process, then this situation disappeared and therefore they learned better. To the results of this research, it can be said that applying MBT method and GI method together contributes to formation of higher quality learning environments.
\end{abstract}

Keywords: Constructivist learning, group investigation method, modeling based teaching method, science education.

\footnotetext{
* This study was based "Effects of Activities Based on Modeling Learning Method and Cooperative Learning Model of Students in Elementary Science and Technology Course" doctoral thesis prepared by Yusuf ZORLU. ** Orcid ID: https://orcid.org/0000-0002-4203-0908, Assist. Prof. Dr., Kütahya Dumlupınar University, Faculty of Education, Department of Elemantry Science Education, yusuf.zorlu@dpu.edu.tr *** Orcid ID: https://orcid.org/0000-0002-1841-4303, Prof. Dr., Atatürk University, KKEF, Department of Elemantry Science Education, fsezek@gmail.com
} 


\section{INTRODUCTION}

The effectiveness, productivity, attractiveness and affordability of instruction in the improvement of students' performances and attitudes towards learning are related to the quality of instruction (Schunk, 2011). The organization of learning environments plays a key role in the provision of quality education. According to Prensky (2008), the organization of learning environments in the twenty-first century should involve the creation of an atmosphere where students are aware of their own learning and assisted to formulate and propose new ideas with mental activities instead of the classical methods that focus on teaching monotonous knowledge and skills. Researchers thus obtain opportunities to realize meaningful learning beyond mere recalling thanks to the activities that are preferred in learning environments (Beyer, 2001). Thinking and selfconfidence are supported by a positive interaction with the guidance of the teachers, which makes learning highly effective (Jones, 2007; Nelson, Ysseldyke, \& Chris, 2015). Furthermore, students' physical skills development can be supported by giving them chance to do exercises based on principles and methods used in the study (Finn, \& McInnis, 2014; Wolf, \& Fraser, 2008).

Learning environments, the abilities that teachers aim to teach students are adopting scientific thinking as a lifestyle, doing studies in fundamentals sciences, developing a positive attitude towards lessons in science, gaining scientific literacy and solving problems experienced in life and living in harmony with the natural environment in science courses (Bozkurt, Orhan, Keskin, \& Mazi, 2008). Concepts are abstract expressions and there are too many complex concepts in the science courses, misconceptions occur because the concepts are not concretizing when they are taught their (Schmidt, 1997; Ural-Keleş, 2009). Teachers should conduct experiments and activities that force students to be active when teaching subjects that include difficult concepts. In some cases, problems in the learning environment can fail to succeed despite teaching the lessons with an active learning method. These can be deficient materials, failure to plan, students' inability to demonstrate their mental skills precisely and teachers' being less active than students (Zorlu, \& Zorlu, 2015). Relevant studies have shown that students rarely use their thinking and correlating skills during lessons, and they are unable to do the experiments and activities or can only do a few of them (Yang, Lee, Hong, \& Lin, 2016; Sezek, Zorlu, \& Zorlu, 2015).

\section{Background of the Study}

If teachers perform activities and experiments in sciences lessons along with the models, methods and techniques used for the creation of an active learning environment, they will prevent these problems in teaching science subjects more easily. The modeling theory that is used with this purpose is based on a model that is founded on scientific theory (Halloun, 2004b, 2006). After mental models are created through analogical reasoning and building structural equations, mental models are expressed using causal diagrams (Satchwell, 1996; Seel, 2001, 2003; Ünal-Çoban, 2009). Modeling-based science education allows students to understand subjects by making correlations and 
solving the problems they have, and developing ideas about these subjects with scientific methods (Lehrer, \& Schauble, 2005; Schwarz, \& White, 2005; Windschitl, Rose, Stalkfleet, \& Smith, 2008). With these procedures, researchers try to involve students in the scientific processes required for teaching the skills that are related to scientific theories and practices through educational programs conducted with students at different educational levels (Halloun, 2006, 2011).

\section{Aim of the Study}

In Modeling based teaching method, it is very important that students help each other to think about subjects, have discussions, do experiments, correlate them to daily life and display superior mental skills such as adapting it to another subject based on their preliminary knowledge. These procedures both reduce the time of learning and enable students to create better mental models (Deniz, 2014; Halloun, 2004a, 2007; ÜnalÇoban, 2009). Cooperative learning is one of the best-known teaching models for providing cooperation among students. In the cooperative learning model, students are divided into heterogeneous groups and try to achieve the goal set for them together (Bayrakçeken, Doymuş, \& Doğan, 2011; Zorlu, 2016; Zorlu, \& Sezek, 2019). Researchers have created several methods to form positive cooperative learning environments. The Group investigation method is one of these methods of the cooperative learning model (Johnson, Johnson, \& Holubec, 1993).

Studies in recent years have found that primary and middle school students in particular have difficulty learning the concepts, generalizations, theories and laws related to science (Bischoff, 2006; Demircioğlu, Demircioğlu, Kongur, \& Ayas, 2004; Er Nas, 2008, 2013; Halloun, 2004a, 2004b, 2006; Ural-Keleş, 2009). The reasons for failing to reach the desired success level despite teaching the lessons with an active learning method include deficient materials, failure to plan, students' inability to demonstrate their mental skills precisely and teachers' being less active than students (Zorlu, \& Zorlu, 2015). However, it is very important in science lessons to determine a suitable method and use it with students to create effective learning environments.

It can be said that one of the most important elements in the formation of constructivist learning approach is learning method. In the studies on the MBT method, it is recommended to use the MBT method with cooperative group studies instead of using it alone at secondary school level (Halloun, 2006, 2007). While MBT method has features such as developing mental skills, learning abstract expressions, and ensuring that teachers and students are active in the lesson (Halloun, 2006, 2007); GI method has the characteristics such as using materials or tools, cooperative learning, better lesson planning, teacher and student being active (Bayrakçeken, Doymuş, \& Doğan, 2013). The fact that the MBT method focuses more on thinking and concretization, and the GI method on cooperative learning through a problem situation, can make the courses more qualified by applying these two methods together. When the related literature was examined, no studies were found where two methods were applied together. With the application of these two methods, it is thought that a well-rounded learning method will 
be presented to the students, determining the contribution of the MDL method to the GA method in terms of constructivist learning environments will contribute to the relevant literature and guide future studies in this field.

The aim of this study was investigated of the effectsofGrup Investigation (GI) method of applying Modeling Based Teaching (MBT) method in the "The Particle Structure and Properties of Matter" unit on constructivist learning.

\section{Problem}

What are the effects of Grup Investigation (GI) method of applying Modeling Based Teaching (MBT) method in the "The Particle Structure and Properties of Matter" unit on constructivist learning?

\section{METHOD}

\section{Research Design}

The study used pretest-posttest quasi-experimental design to compare groups that studied with multiple methods and to making internal comparisons for the groups (Figure 1). There were two experimental groups (EG1 and EG2) in the research design. EG1 studied with the Group investigation (GI) and existing method (Seventh Science Course Curriculum), while EG2 studied with both the Group Investigation and Modeling Based Teaching methods.

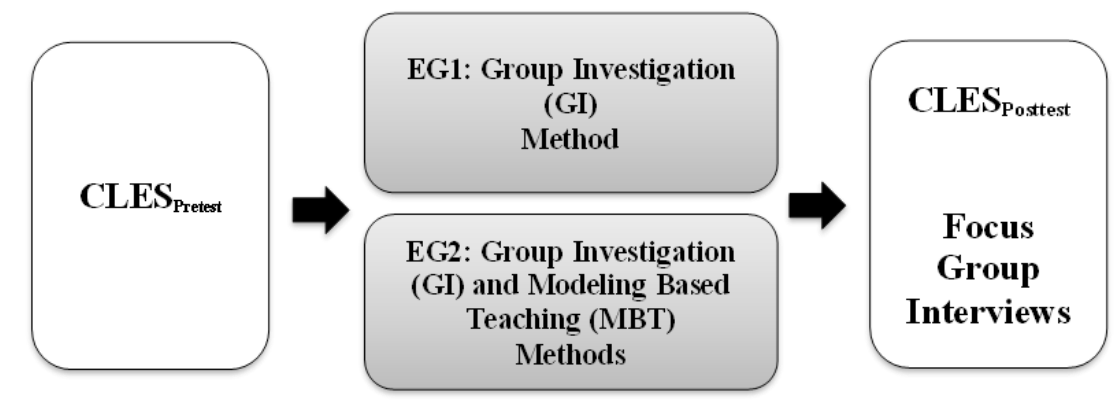

Figure 1.Application of Research Design

\section{Application of Experimental Groups (EG1 and EG2)}

Based on the recommendations in the relevant literature, it was decided to apply the MBT method together with the GI method instead of applying it alone. In order to investigate the effect of this application, it was decided to apply GI method to another group in seventh grade. In EG1 and EG2, the "The Particle Structure and Properties of Matter" unit was processed in 7 weeks.

The researchers used Doymuş (2012)'s GI method (EG1). At first, the students were administered pretest. The students were divided into two parts according to the results obtained from the pretest (Part 1 and Part 2). Heterogeneous groups were formed for each the part according to the results obtained from the pretest. Then, in the context of the unit, the heterogeneous groups were given each sub-topic of the unit and asked to share them. The heterogeneous groups were also brought together outside the school 
and were asked to do research. When they came to the classroom, they reviewed their research on the subject for the last time and tried to learn the subject. Then a part was determined by lot. In this part, the presentation heterogeneous group was determined by lot. In other part, the check heterogeneous group was determined by lot. While the the presentation group made the presentation, the check group identified their deficiencies and mistakes. Afterwards, questions were taken from the other heterogeneous groups in the classroom and asked questions to the presentation group. After eliminating the deficiencies, the next sub-topic was given. Other sub-topics of the unit were processed in the same way.

With EG2, the researcher used a MBT method in addition to the GI method used with EG1. This study used Ünal-Çoban (2009)'s MBT method (Figure 2). In EG2, in addition to the sub-topics, the activities of the MBT were given (Figure 2). All students are responsible for the activities. When the students did research on their sub-topics and came to the classroom, they carried out activities and courses of the MBT. After the end of the activities, the presentation and the check groups were determined as in EG1. The heterogeneous group who made the presentation also presented what they wrote on the activity sheet. After eliminating the deficiencies, the next sub-topic was given. Other subtopics of the unit were processed in the same way.

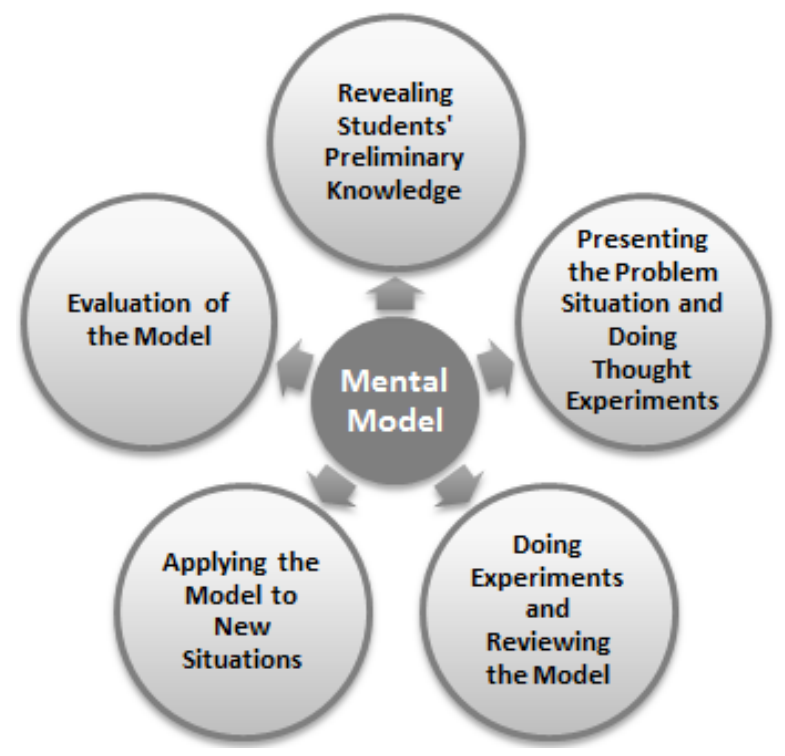

Figure 2. The Modeling Based Teaching (MBT) Method of Ünal-Çoban (2009)

Here are the practical steps of Ünal-Çoban (2009)'s MBT method:

1) Revealing Students' Preliminary Knowledge: This study attempted to determine students' knowledge learned at school or by experience as well as their pre-existing models related to the subject. After the students expressed their mental models, they were asked to discuss these mental models with their groups, and determine which model explained the subject problem best and why. 
2) Presenting the Problem Situation and Doing Thought Experiments: Based on the mental models determined in the previous step and the open model presented beforehand, the researchers gave a problem situation related to the main subject to be studied. The researchers also discussed the suitability of the problem for the previous model. The students were asked to show the problem situation in their mental models and match it with the open model. Then, the students determined the problem of the thought experiment, and made preliminary use of the model in the problem solving stage by making a structural match between the situation with the problem and the situation described by the model. In the thought experiment section, the students were expected to reason about the patterns based on their similarities. Thus, the number of variables was increased in the second section, and the students were asked to estimate results by correlating variables.

3) Doing Experiments and Reviewing the Model: In this stage, the researchers had the students do scientific experiments. The experiment involved collecting and analyzing the data and evaluating results considering the model.

4) Applying the Model to New Situation: The researchers helped students to see how practical the model they obtained by having them use it to solve different problems and explain phenomena as well as in activities and making analogies.

5) Evaluation of the Model: In this stage, the relation between the model and the theory was evaluated and matched with the reality it represented. The scope of the model was determined by revising it when necessary. In this section, the researchers selected a group by lot and asked them to present their activities to the class. Then, the groups had discussions and finalized their models. They did the exercises in their textbooks, and the researchers assigned some of these exercises to them as homework. Finally, the researchers gave module tests to students on the subject and asked them to answer the questions personally within the allotted duration. Afterwards, the exercises were solved with the entire class, and the subject was reviewed.

\section{Sample}

The study sample was selected using simple random sampling. The researcher randomly selected two seventh grade groups in this school and a public middle school in Erzurum province center. A group (EG1) of 31 students was administered the GI method, and a group (EG2) of 33 students was administered the MBT and GI methods together.

\section{Data Collection}

Research quantitative dimension. Before and after the implementation, the researchers administered the CLES to the students. This scale was created by Tenenbaum, Naidu, Jegede and Austin (2001), and translated and adapted to Turkish by Fer and Cirlk (2007). It is a Likert-type scale with the responses: "none" (1 points), "hardly" (2 points), "partially" (3 points), "highly" (4 points) and "entirely" (5 points). The minimum score on the CLES is 30 , and the maximum score is 150 . The scale has seven subfactors and 30 items. Its subfactors were discussions and interviews, conceptual discrepancies, sharing views with others, materials and resources, reflection and motivation for discovering 
concepts, meeting the needs of learners, and establishing meanings and correlations with real life events. The reliability coefficient of the scale (Cronbach Alpha) was .89. At this research, the reliability coefficient of the scale (Cronbach Alpha) was .91.

Research qualitative dimension. Focus group interviews are one of the most effective methods for qualitative data collection (Ylldırım and Şimşek, 2005). They are used with qualitative scales to help determine the causes of study results more comprehensively (Wilkinson, 2004). Focus group interviews were held in order to determine the reasons of the results obtained from CLES. The focus group interviews were held by taking into account the factors of the CLES. The researcher also held focus group interviews with the students to see the extent to which these themes characterized the implementation. The heterogeneous group (consisted of five students (EG1.A1 student- EG1.E1 student)) from EG1 and the heterogeneous group (consisted of five students (EG2.A2 studentEG2.E2 student)) from EG2 were selected randomly, and they attended interviews that lasted approximately 30 minutes. The students were asked to respond to the questions considering the implementation process in the focus group interviews. Before the focus group interviews were held, the students were informed that the focus group interviews were aimed at the practice, that they would be held under seven headings and that they would express their views in a neutral and positive way. If there is no unclear situation after the information was given, focus group interviews were held.

\section{Data Analysis}

When using the scale, the researcher initially examined the equivalence of the students in the study groups. While testing the effect of the independent variable on the dependent variable, covariance analysis (ANCOVA) is used when it is necessary to control the effect of another variable that is thought to be able to affect the dependent variable (Pallant, 2013). The covariance analysis (ANCOVA) was used because it was necessary to check the CLES pretest effect which was thought to affect CLES posttest for see whether there were statistically significant differences between the posttest scores of the students in groups.

In the analysis of qualitative data, descriptive analysis is done by using literature or by using previously created themes and codes (Yıldırım, \& Şimşek, 2005). Obtained all data from CLES were anonymized by ensuring participants did not use names during interviews. The qualitative data obtained from the focus group interview were analyzed by descriptive analysis method according to CLES. The categories used in focus group interviews were taken from the factors and items in CLES. The qualitative data were coded by two researchers. The themes and codes were agreed by two researchers and were finalized.

\section{FINDINGS}

Before and after the application, the researcher administered Constructive Learning Environment Scale (CLES) to the students. 


\section{Table 1.}

Descriptive and ANCOVA result for the CLES (Pretest-Posttest)

\begin{tabular}{|c|c|c|c|c|c|c|c|}
\hline Tests & Groups & $\mathrm{N}$ & $\mathrm{X}$ & SD & $\mathrm{X}^{\mathrm{a}}$ & $\mathrm{SE}^{\mathrm{a}}$ & \\
\hline \multirow{2}{*}{ CLES (Pretest) } & EG1 & 31 & 118.55 & 12.78 & - & - & \\
\hline & EG2 & 33 & 115.79 & 17.53 & & & \\
\hline \multirow{2}{*}{ CLES (Posttest) } & EG1 & 31 & 124.90 & 15.49 & 124.30 & 2.00 & \\
\hline & EG2 & 33 & 135.58 & 9.55 & 136.14 & 1.93 & \\
\hline Source & Sum of Square & $\mathrm{df}$ & Mean Square & $\mathrm{F}$ & $\mathrm{p}$ & $\eta^{2}$ & Different \\
\hline CLES(Pretest) & 2613.986 & 1 & 2613.986 & 21.270 & .000 & .259 & EG2-EG1 \\
\hline Groups & 2220.586 & 1 & 2220.586 & 18.069 & .000 & .229 & \\
\hline Error & 7496.784 & 61 & 122.898 & & & & \\
\hline Corrected Total & 11931.438 & 63 & & & & & \\
\hline
\end{tabular}

Table 1 shows that there is a significant difference between the groups to the advantage of EG2 for the posttest data, $\mathrm{F}(1-63)=18.069 ; \mathrm{p} \leq 0.05$. The eta-squared value indicated by the posttest was .229. This explained $23 \%$ of the difference between the scores. The researcher analyzed the factors included in the CLES with the purpose of determining the factors that created the contribution of the MBT method to the GI method regarding the learning environment (Table 2).

\section{Table 2.}

ANCOVA results for the factors of CLES (Posttest)

\begin{tabular}{|c|c|c|c|c|c|c|c|c|}
\hline Factors & Source & $\begin{array}{l}\text { Sum of } \\
\text { Square }\end{array}$ & $\mathrm{df}$ & $\begin{array}{c}\text { Mean } \\
\text { Square }\end{array}$ & $\mathrm{F}$ & $\mathrm{p}$ & $\eta^{2}$ & Different \\
\hline $\begin{array}{l}\text { Discussions and } \\
\text { Interviews }\end{array}$ & Groups & 45.993 & 1 & 45.993 & 5.855 & .019 & .088 & EG2-EG1 \\
\hline Conceptual Discrepancies & Groups & 133.637 & 1 & 133.637 & 16.205 & .000 & .210 & EG2-EG1 \\
\hline $\begin{array}{l}\text { Sharing Views with } \\
\text { Others }\end{array}$ & Groups & 27.721 & 1 & 27.721 & 6.332 & .015 & .094 & EG2-EG1 \\
\hline $\begin{array}{l}\text { Materials and resources } \\
\text { aiming to reach to } \\
\text { solution }\end{array}$ & Groups & 3.853 & 1 & 3.853 & 1.433 & .236 & .023 & \\
\hline $\begin{array}{l}\text { Reflection and } \\
\text { motivation for } \\
\text { discovering concepts }\end{array}$ & Groups & 39.071 & 1 & 39.071 & 5.081 & .028 & .077 & EG2-EG1 \\
\hline $\begin{array}{l}\text { Meeting the needs of } \\
\text { learners }\end{array}$ & Groups & 67.970 & 1 & 67.970 & 14.410 & .000 & .191 & EG2-EG1 \\
\hline $\begin{array}{l}\text { Establishing meanings, } \\
\text { and correlation with real } \\
\text { life events }\end{array}$ & Groups & 12.046 & 1 & 12.046 & 3.145 & .081 & .049 & \\
\hline
\end{tabular}

Table 2 shows that the students in EG2 had higher posttest arithmetic means than the students in EG1 for the factors of discussions and interviews, conceptual discrepancies, sharing views with others, reflection and motivation for discovering concepts and 
meeting the needs of learners. The difference between the groups was statistically

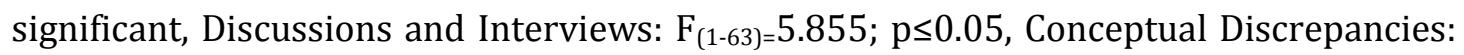

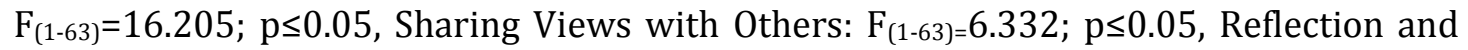

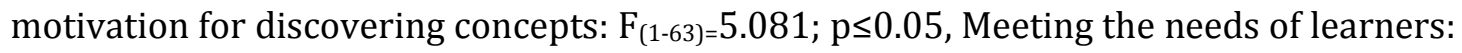

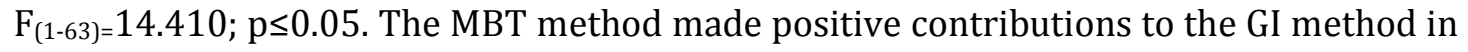
relation to these five factors.

After the implementation was completed, the researcher held focus group interviews with the seventh graders in the experimental groups with the assistance of the CLES. Table 3-9 are the data from these interviews.

Table 3.

Descriptive analysis results for the "Discussions and Interviews" theme

\begin{tabular}{|c|c|c|c|c|}
\hline Views from EG1 & Views from EG2 & Codes & EG1 & EG2 \\
\hline $\begin{array}{l}\text {-We discussed the } \\
\text { subjects we had conflicts } \\
\text { about (EG1.E1 student). } \\
\text {-We made summaries. } \\
\text { We discussed the } \\
\text { summaries when doing } \\
\text { group work (EG1.D1 } \\
\text { student) } \\
\text {-The groups stood up in } \\
\text { front of the class. We } \\
\text { asked questions about } \\
\text { the subjects we knew } \\
\text { nothing or little about } \\
\text { (EG1.A1 student) } \\
\text {-We had discussions } \\
\text { during and after each of } \\
\text { the subjects (EG1.C1 } \\
\text { student). }\end{array}$ & $\begin{array}{l}\text {-We exchanged ideas, and determined } \\
\text { our deficiencies. We discussed our } \\
\text { views (EG2.A2 student). } \\
\text {-Every member of the group expressed } \\
\text { personal views when learning a new } \\
\text { subject. We tried to learn by } \\
\text { brainstorming (EG2.B2 student). } \\
\text {-When we learned the subject better, } \\
\text { this helped us to improve our } \\
\text { knowledge (EG2.C2 student). } \\
\text {-Our peers told their views about the } \\
\text { subject. We tried to reach correct } \\
\text { knowledge using these views (EG2.D2 } \\
\text { student). } \\
\text {-We made interpretations in the } \\
\text { thought experiments given on the } \\
\text { worksheets. We reached certain results } \\
\text { based on these interpretations (EG2.E2 } \\
\text { student). } \\
\text {-The teachers talked to the groups and } \\
\text { helped us with the subjects we did not } \\
\text { know about when we were doing the } \\
\text { exercises on the worksheets, which } \\
\text { increased our participation in the } \\
\text { lesson (EG2.B2 student). } \\
\text {-We learned new information about } \\
\text { the subject thanks to the experiments } \\
\text { we did (EG2.D2 student). }\end{array}$ & $\begin{array}{l}\text { Having } \\
\text { Discussions and } \\
\text { Interviews During } \\
\text { the Course } \\
\text { Teaching the } \\
\text { Lesson Through } \\
\text { the Exchange of } \\
\text { Ideas } \\
\text { Teaching the } \\
\text { Lesson Through A } \\
\text { Comparison of } \\
\text { Different } \\
\text { Perspectives } \\
\text { Encouraging } \\
\text { Students to Put } \\
\text { Express Views } \\
\text { Freely } \\
\text { Improving Mental } \\
\text { Perspectives }\end{array}$ & $\checkmark$ & $\checkmark$ \\
\hline
\end{tabular}

When the student views in Table 3 are examined, it is seen that there are statements for "Having Discussions and Interviews During the Course", "Teaching the Lesson Through the Exchange of Ideas", "Teaching the Lesson Through A Comparison of Different 
Perspectives" and "Encouraging Students to Put Express Views Freely" codes. However, it is seen that the students in EG2 have "Improving Mental Perspectives" code expressions in their views. The students in EG2 stated that the practices enabled thinking and improved their mental perspectives.

Table 4.

Descriptive analysis results for the "Conceptual Discrepancies" theme

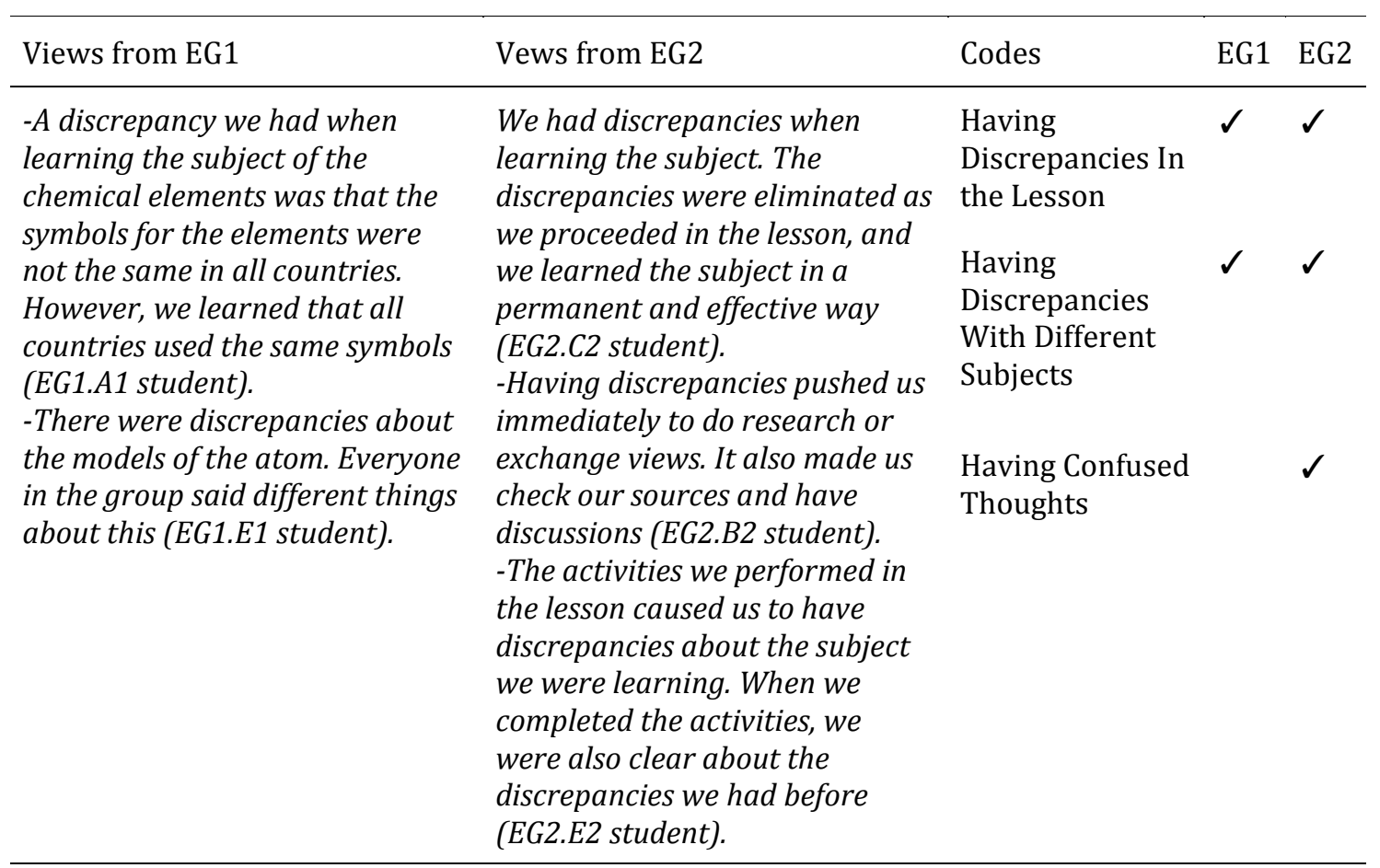

When Table 4 are examined, it is seen that unlike EG1, the students' views in EG2 have expressions belonging to the "Having Confused Thoughts" code. It is seen that the students in EG1 and EG2 stated that they have experienced conceptual discrepancies on subjects that contain difficult and abstract statements in their views. Unlike EG1, students in EG2 seem to be experiencing contradictions due to some of the abstract statements as well as some of the activities involved in the subject matter, which in turn lead to having confused thoughts. The students said that they were illuminated by the activities on the subjects they were in, and that there were contradictions and their illumination enabled them to learn the subject in a more permanent way. 


\section{Table 5.}

Descriptive analysis results for the "Sharing Views with Others" theme

\begin{tabular}{|c|c|c|c|c|}
\hline Views from EG1 & Views from EG2 & Codes & EG1 & EG2 \\
\hline $\begin{array}{l}\text {-We divided the subjects } \\
\text { into subtopics. Then, every } \\
\text { member of the group } \\
\text { explained the subjects } \\
\text { they studied to the group } \\
\text { (EG1.A1 student). } \\
\text {-We shared the tasks. } \\
\text { When we came to the } \\
\text { class for lesson, we shared } \\
\text { and explained the subjects } \\
\text { to each other (EG1.B1 } \\
\text { student). } \\
\text {-We did this sharing with } \\
\text { summaries (EG1.D1 } \\
\text { student). } \\
\text {-We learned the lesson by } \\
\text { sharing when we were } \\
\text { studying as a group. This } \\
\text { helped us comprehend the } \\
\text { subject better (EG1.C1 } \\
\text { student). }\end{array}$ & $\begin{array}{l}\text {-Before coming to the lesson, we } \\
\text { prepared summaries of the subject. } \\
\text { We read these summaries when we } \\
\text { came to the class. We also explained } \\
\text { them to each other (EG2.A2 student). } \\
\text {-After we learned the subject, one of } \\
\text { the groups stood in front of the class } \\
\text { and explained the subject to the rest } \\
\text { of the students. Another group asked } \\
\text { questions after they told the subject. } \\
\text { Therefore, we learned new subjects by } \\
\text { discussion (EG2.B2 student) } \\
\text {-We shared our knowledge with our } \\
\text { groups. When there were points we } \\
\text { did not know about, we asked to our } \\
\text { teacher. This helped us reinforce the } \\
\text { subject we were learning (EG2.D2 } \\
\text { student) } \\
\text {-When doing the experiment on the } \\
\text { worksheet, everyone in the group } \\
\text { shared what they knew about it. This } \\
\text { helped us see our deficiencies and } \\
\text { learn better (EG2.A2 student). }\end{array}$ & $\begin{array}{l}\text { Teaching the } \\
\text { Lessons Through } \\
\text { Social Interaction } \\
\text { Teaching the } \\
\text { Lessons Through } \\
\text { Different and } \\
\text { Diversified } \\
\text { Learning Methods } \\
\text { Giving Students } \\
\text { the Chance to } \\
\text { Express } \\
\text { Themselves }\end{array}$ & $\checkmark$ & $\checkmark$ \\
\hline
\end{tabular}

When the student views in Table 5 are examined, it is seen that there are statements for all codes "Sharing Views with Others" theme. In the focus group interviews, it is seen that the students expressed made preparations before the lesson and wrote summaries, studied the subjects in the lesson, had discussions with each other and interactions with the teacher and did the exercises on the worksheet together in their views. It is seen that they also expressed that when one of the group members stood up and explained and discussed the subject with the class, it helped them learn the subject better and share their thoughts in their views. 
Table 6.

Descriptive analysis results for the "Reflection and Motivation for Discovering Concepts" theme

\begin{tabular}{|c|c|c|c|c|}
\hline Views from EG1 & Views from EG2 & Codes & EG1 & EG2 \\
\hline $\begin{array}{l}\text {-Learning the subject by } \\
\text { ourselves encouraged us } \\
\text { to pay attention to the } \\
\text { lesson and the subject } \\
\text { (EG1.B1 student). } \\
\text {-Writing summaries } \\
\text { made us prepare for the } \\
\text { lesson. This made me } \\
\text { participate in the lesson. } \\
\text { It also improved my self- } \\
\text { confidence (EG1.D1 } \\
\text { student). } \\
\text {-I was willing to respond } \\
\text { to all of the questions } \\
\text { because I was capable of } \\
\text { giving responses. It } \\
\text { increased my motivation } \\
\text { for the lesson (EG1.E1 } \\
\text { student). }\end{array}$ & $\begin{array}{l}\text {-We became closer to each other as } \\
\text { classmates as we worked in groups and } \\
\text { learned the lesson through activities } \\
\text { (EG2.A2 student). } \\
\text {-Our classmates who were sitting in the } \\
\text { back seats were not very participative } \\
\text { during lessons. Being taught the lesson } \\
\text { by in-group discussions and activities } \\
\text { helped them to get involved in the } \\
\text { lesson (EG2.B2 student). } \\
\text {-We also did thought experiments using } \\
\text { the worksheets. These thought } \\
\text { experiments helped me improve my } \\
\text { thinking skills. I also learned the } \\
\text { concepts better thanks to the } \\
\text { experiments (EG2.E2 student). } \\
\text {-We did experiments and activities } \\
\text { during the lesson. We thought about } \\
\text { the subject and mental visualized it. } \\
\text { This helped me learn the subject better. } \\
\text { It motivated me as well (EG2.D2 } \\
\text { student). } \\
\text {-When we were learning the subject, we } \\
\text { inquired about the concepts more } \\
\text { comprehensively to learn them. For } \\
\text { example, we made an effort to learn all } \\
\text { aspects of cathodes and anodes rather } \\
\text { than just recognizing them as positive } \\
\text { and negative (EG2.C2 student) }\end{array}$ & $\begin{array}{l}\text { Encouraging } \\
\text { Learning by } \\
\text { Analyzing the } \\
\text { Subject From } \\
\text { Different } \\
\text { Perspectives } \\
\text { Encouraging } \\
\text { Learning Based on } \\
\text { Different Views } \\
\text { From Peers } \\
\text { Learning to } \\
\text { Question the } \\
\text { Things Learned So } \\
\text { Far } \\
\text { Learning to Use } \\
\text { the Knowledge } \\
\text { Learned So Far }\end{array}$ & $\checkmark$ & $\checkmark$ \\
\hline
\end{tabular}

When Table 6 are examined, it is seen that unlike EG1, the students' views in EG2 have expressions belonging to the "Learning to Question the Things Learned So Far" and "Learning to Use the Knowledge Learned So Far" codes. It is seen that the students in EG1 expressed getting prepared before the lesson increased their participation and motivation, increased their self-confidence and encouraged them to learn the subjects by them in their views. It is seen that the students in EG2 expressed they got motivated for deeper thinking, learned to use their knowledge, examined the subject with all aspects, participated more in the lesson thanks to group work and activities, learned the concepts better and improved their thinking skills, which increased their motivation and encouraged them to learn in their views. 


\section{Table 7.}

Descriptive analysis results for the "Meeting the Needs of Learners" theme

\begin{tabular}{|c|c|c|c|c|}
\hline Views from EG1 & Views from EG2 & Codes & EG1 & EG2 \\
\hline $\begin{array}{l}\text {-In general, our needs were } \\
\text { satisfied. The subject of } \\
\text { chemical bonds was really } \\
\text { complicated, and we were } \\
\text { not fully successful in } \\
\text { learning it. It was partly the } \\
\text { teacher's assistance that } \\
\text { made us learn (EG1.A1 } \\
\text { student). } \\
\text {-When we learned the } \\
\text { subject better, we were very } \\
\text { happy (EG1.D1 student). } \\
\text {-We were happy to learn } \\
\text { what we had not known } \\
\text { before, and share it with our } \\
\text { friends (EG1.B1 student). } \\
\text {-In the lesson, we were } \\
\text { unhappy to hear our friends } \\
\text { say that we were noisy } \\
\text { (EG1.C1 student). }\end{array}$ & $\begin{array}{l}\text {-This method helped some of our } \\
\text { classmates to participate in the } \\
\text { lesson who could not get too } \\
\text { connected with the lesson before. } \\
\text { They also got more interested in the } \\
\text { lesson (EG2.B2 student). } \\
\text {-It also made me happy to study as a } \\
\text { group, and do activities and } \\
\text { experiments because I learned the } \\
\text { subjects in the lesson (EG2.A2 } \\
\text { student). } \\
\text {-We made analogies at the beginning } \\
\text { of each lesson. It was challenging for } \\
\text { us to make these analogies. Then we } \\
\text { correlated these analogies with our } \\
\text { thoughts and learned the subject by } \\
\text { experiments and similar activities } \\
\text { (EG2.D2 student). } \\
\text {-When doing the activities, we made } \\
\text { comparisons between what we } \\
\text { learned between the thought } \\
\text { experiment and the scientific } \\
\text { experiment. Even if we had great } \\
\text { difficulty making these comparisons, } \\
\text { we recognized that we eliminated } \\
\text { the deficiencies in our knowledge } \\
\text { when we finished it (EG2.E2 student). } \\
\text {-While the lesson was being taught, I } \\
\text { recognized what I did and did not } \\
\text { know. Being aware of my deficiencies } \\
\text { helped me learn the subject better } \\
\text { (EG2.C2 student). }\end{array}$ & $\begin{array}{l}\text { Teaching the } \\
\text { Lesson In } \\
\text { Accordance } \\
\text { With the Needs } \\
\text { and Interests of } \\
\text { Students } \\
\text { Students Are } \\
\text { Happy About } \\
\text { What They } \\
\text { Learn }\end{array}$ & $\checkmark$ & $\checkmark$ \\
\hline
\end{tabular}

When Table 7 are examined, it is seen that unlike EG1, the students' views in EG2 have expressions belonging to the "Students Learn To Make Use of Learning Difficulties" and "Students Become Capable of Tracking Individual Goals" codes. It is seen that the students in EG1 expressed their needs and interests related to learning were satisfied in general, and they were happy with what they learned in their views. However, according to the students' views, it is seen that they are negatively affected by the noise generated during the studies. The students in EG2 said that the methods or techniques used in the lessons satisfied their needs and interests, and they were happy with what they had learned. The students in EG1 said they had difficulty with the hard subjects in the unit, and they realized that they had other deficiencies when dealing with them. On the other hand, the students in EG2 said that they had difficulty at the beginning of each lesson no 
matter whether the subject that day was easy or difficult, that these difficulties were eliminated when the lesson was being taught, and that their deficiencies were eliminated. These findings indicate that the modeling learning method helped students to learn subjects or concepts by making use of learning difficulties and track themselves personally.

\section{RESULTS, DISCUSSIONS AND SUGGESTIONS}

A well-designed learning environment improves the learning process and enhances the quality of education. Constructivist learning environments consider students' preliminary knowledge, skills, interests and needs and go beyond the student-centered approach by guiding the effect of active participation on learning (Köseoğlu, \& Tümay, 2015). With the purpose of creating well-designed constructivist learning environments, the methods that realize learning by construction and enable both students and teachers to be active have begun to be employed at a variety of educational levels in place of learning methods that activate only students or only teachers. This study demonstrates the effects of constructivist learning environments and constructivism, the basic philosophy of the methods used in science instruction. Thus, the study held focus group interviews using CLES to analyze these learning environments.

According to the findings obtained from the CLES posttest, it was found that the group in which MBT and GI methods were applied together was statistically better than the group in which GI method was applied (Table 1 and Table 2). The students' learning has a positive and linear relationship with constructivist learning approach. The more the method used during the learning provides the characteristics of the constructivist learning approach, the better and lasting learning of the subjects can be provided (Fer, \& Cırık, 2007; Köseoğlu, \& Tümay, 2015). According to this result, it can be said that applying of MBT and GI methods together developed more the constructivist learning environment than applying of GI method. When we investigate the results of studies in literature which modeling based teaching and different learning methods are applied together, it is seen that these applications increase learning (Aragon, Oliva, \& Navarrete, 2014; Gilbert, 2004; Halloun, 2004a, 2006; Justi, \& Gilbert, 2002; Nunez-Oviedo, 2004; Oliva, Aragon, \& Cuesta, 2014; Ünal-Çoban, 2009).

According to the findings obtained from "Discussions and Interviews" and "Sharing Views with Others" factors, it was found that the group in which MBT and GI methods were applied together was statistically better than the group in which GI method was applied (Table 1 and Table 2). In the focus group interview, it was seen that the students in group which were applied MBT and GI methods together expressed views about Improving Mental Perspectives code in "Discussions and Interviews" theme unlike GI students. The students in group which were applied MBT and GI methods together stated that there are applications that provide thinking and improve their mental perspectives. When students were sharing with their classmates the knowledge they learned in MBT method and performing the activities, they said the thinking activity was 
at the top level (Justin, \& Gilbert, 2002; Nunez-Oviedo, 2004; Ünal-Çoban, \& Ergin, 2011). As a result, students structured their knowledge through superior thinking and shared it with each other. Supporting and developing students' thinking in interaction is effective in the realization of learning (Jones, 2007; Nelson, Ysseldyke, \& Chris, 2015). In the focus group interviews; they stated that the practices developed their mental perspectives, that they could look at the issue from different perspectives, that they discussed about the subject and that they could express their own opinions during the process. A number of studies have also proved that modeling improves students' ability to use their minds and taught them new mental views (Gilbert, 2004; Halloun, 2004b, 2011). The development of mental views help students create different thoughts and learn different aspects of knowledge (Brooks, \& Brooks, 1999; Tenenbaum et al., 2001). According to these results, it can be said that the students had more discussions in the lessons and had more discussions about the subjects with the application of MBT and GA methods together.

In the findings obtained from the "Conceptual Discrepancies" factor, it was found that the students in group which were applied MBT and GI methods together was statistically better than the students in group which were applied GI method (Table 1 and Table 2). In the focus group interview, it was seen that the students in group which were applied MBT and GI methods together expressed views about "Having Confused Thoughts" code in "Conceptual Discrepancies" theme unlike students in group which were applied GI method. While the students in group which were applied MBT and GI methods together stated that they experienced conceptual contradictions because of activities belonging to MBT method, not on difficult subjects that contain abstract expressions while they were teaching, and that the contradictions disappeared at the end of the application and they learned the subject better; the students in group which were applied the GI method stated that they experienced conceptual contradictions only on difficult subjects and that all of these contradictions did not disappear. In science education, the modeling theory is related not only to the conceptual worlds of students, but also to physical facts and the areas that are in contrast with science in particular. Thus, it is one of the purposes of this method to give students conceptual discrepancies (Halloun, 2004a, 2006). This inconsistency in relations is an internal harmony between an existing concept and some other entities, since students have conceptual discrepancies due to these inconsistencies (Ünal-Çoban, 2009; Ünal-Çoban, \& Ergin, 2011). Because students experience conceptual contradictions due to conflicts. Conceptual discrepancies help students learn better and more permanently (Fer, \& Cirık, 2007; Tenenbaum et. al, 2001). In addition, it is seen in the statements of students that the fact that abstract expressions take place in science courses leads to confusion of concepts and the confusion was eliminated with the concretization of the activities of MBT. Concepts are abstract expressions and there are too many complex concepts in the science courses, misconceptions occur because the concepts are not concretizing when they are taught their (Schmidt, 1997; Ural-Keleş, 2009). One of the characteristics of appropriate learning environments is to teach the knowledge through the concretizing. Students can be active in order to turn scientific 
thinking into a way of life, to develop positive attitudes towards science courses, to encourage studies in basic sciences, and to increase knowledge and skills by teaching by concretizing knowledge (Bozkurt, Orhan, Keskin, \& Mazi, 2008). It can be said that constructivist learning environment has been developed by creating a learning environment that will help to eliminate the problems experienced in the learning process. According to these results, it can be said that students learn through conceptual contradictions and eliminate these contradictions by applying the MBT and GI methods together.

In the findings obtained from the "Reflection and Motivation for Discovering Concepts" and "Meeting the Needs of Learners" factors, it was found that the students in group which were applied MBT and GI methods together was statistically better than the students in group which were applied GI method (Table 1 and Table 2). In the focus group interview, it was seen that unlike students in group which were applied GI method the students in group which were applied MBT and GI methods together expressed views about "Learning to Question the Things Learned So Far" and "Learning to Use the Knowledge Learned So Far" codes in "Reflection and Motivation for Discovering Concepts" theme, and "Students Learn To Make Use of Learning Difficulties" and "Students Become Capable of Tracking Individual Goals" codes in "Meeting the Needs of Learners" theme. It is seen that the students in EG2 expressed they got motivated for deeper thinking, learned to use their knowledge, examined the subject with all aspects, participated more in the lesson thanks to group work and activities, learned the concepts better and improved their thinking skills, which increased their motivation and encouraged them to learn in their views. According to this result, it can be said that the students learned the subjects with awareness and questioning through the MBT worksheets (activities). During the interviews, the students in EG2 said that, although they had difficulty comparing thought experiments and scientific experiments and making analogies between them, they learned the subjects by overcoming these difficulties and were able to attain the lesson goals better. Overcoming challenges and learning the subjects prove that students made an effort to achieve their goals. Students can only make efforts during the learning process by playing an active role in the learning environment. It is possible for the students to take an active part in the learning environment. This provides more meaningful learning (Halloun, 2006, 2007; Justi, \& Gilbert, 2002; Ünal-Çoban, 2009; Zorlu, \& Zorlu, 2015). High rates of conceptual discrepancies, discussions and interviews and thought sharing help students become aware of the things they have learned and become aware of their deficiencies (Baş, \& Beyhan, 2012). Students can discover the information themselves by being aware of what they have learned. The phenomenon of comprehension occurs when they discover new information. The concept of comprehension becomes good and lasting learning (Abdullah, \& Shariff 2008; Odunbunni, \& Balagun, 1991; Souvignier, \& Kronenberger, 2007; Zorlu, Zorlu, Sezek, \& Akkuş, 2014; Sezek, Zorlu, \& Zorlu, 2015).

In the classroom, students may have different learning styles. The learning methods used in learning a subject should have different characteristics and should be 
elaborated. Bringing together different learning methods that enable different learners to learn means more wealth and learning opportunities. A well-designed learning environment enables students to acquire new knowledge and skills and have rich, guided learning experiences (Schunk, 2011). According to the results of the study; for greater wealth and learning opportunities, rather than simply applying the GI method, MBT can be applied in conjunction with MBT to enable students to experience more qualified constructivist learning environments. Using both the MBT method and different techniques in the cooperative learning model will eliminate potential deficiencies created by using only one method and make learning more effective. The relevant literature contains a number of studies that suggest using the MBT method and the cooperative learning model together (Gilbert, 2004; Halloun, 2006; Ünal-Çoban, 2011). In future studies, applying the MBT method to the cooperative learning method with different techniques and determining its benefits for learning environments will contribute to the literature.

\section{References}

Abdullah, S., \& Shariff, A. (2008). Theeffects of inquiry-based computer simulation with cooperative learning on scientific thinking and conceptual understanding of gaslaws. Eurasia Journal of Mathematics, Science \& Techology Education, 4(4), 387398.

Ames, C. (1992). Classrooms: Goals, structures, and student motivation. Journal of educational psychology, 84(3), 261.

Aragon, M. D. M., Oliva, J. M., \& Navarrete, A. (2014). Contributions of learning through analogies to the construction of secondary education pupils' verbal discourse about chemical change. International Journal of Science Education, 36(12), 19601984. doi: 10.1080/09500693.2014.887237

Baş, G., \& Beyhan, Ö. (2012). Assessment of graduate theses on value education in Turkey in terms of different variables [Türkiye'de değerler eğitimi konusunda yapılmış lisansüstü tezlerin farklı değişkenler açısından değerlendirilmesi]. Değerler Eğitimi Dergisi [Values Education Journal], 10(24), 55-77.

Bayrakçeken, S., Doymuş, K., \& Doğan, A. (2013). Collaborative learning model and its application [İşbirlikli öğrenme modeli ve uygulaması] (1st Edit.). Ankara: Pegem Akademi.

Beyer, B. (2001). Putting it all together to improve student thinking. In A.C. Costa (Ed.), Developing minds: A resource book for teaching thinking (3rd Edit.), (pp. 417-424). Alexandria, VI: ASCD.

Bischoff, P. J. (2006). The role of knowledge structures in the ability of preservice elementary teachers to diagnose a child's understanding of molecular kinetics. Science Education, 90(5), 936-951. doi: 10.1002/sce.20155 
Bozkurt, O., Orhan, A. T., Keskin, A., \& Mazi, A. (2008). The effect of cooperative learning method to the academic achievement in science and technology lesson [Fen ve teknoloji dersinde işbirlikli öğrenme yönteminin akademik başarıya etkisi]. Türkiye Sosyal Araştırmalar Dergisi, 2, 63-78.

Brooks, J. G. \& Brooks, M. G. (1999). In search of understanding: The case for constructivisit classrooms. Alexandria, VA: Association for Supervision and Curriculum Development.

Demircioğlu, H., Demircioğlu, G., Kongur, S., \& Ayas, A. (2004). Comparison of theoretical and practical information on the concept of mass conservation of high school students [Lise ögrencilerinin kütlenin korunumu kavramı ile ilgili teorik ve uygulama bilgilerinin karşılaştırılması], paper presented at the VI. Ulusal Fen Bilimleri ve Matematik Eğitimi Kongresi, Marmara University, İstanbul.

Deniz, D. (2014). The sufficiency of high school mathematics teachers' to elicit and apply activities appropriate to mathematical modelling method. Unpublished Doctoral Dissertation. Atatürk University.

Doymuş, K. (2012). Informing of science and technology teachers applications of cooperative learning model, in the class and evaluating the obtained results (110K252). The TUBITAK Project.

Er-Nas, S. (2008). Determining effectiveness of the materials about? The ways of spread of heat? Based on the elaborate stage of the 5E model. Unpublished Master's Thesis. Karadeniz Teknik University.

Er-Nas, S. (2013). Evaluating effectiveness of the guide material about transferring concepts to daily life in elaborate stage in matter and heat unit. Unpublished Doctoral Dissertation. Karadeniz Teknik University.

Fer, S. \& Cirık, İ. (2007). What is the validity and reliability of the constructivist learning environment scale in teachers and students? [Öğretmenlerde ve öğrencilerde, yapılandırmacı öğrenme ortamı ölçeğinin geçerlilik ve güvenirlik çalışması nedir?], Yeditepe Üniversitesi Eğitim Fakültesi Dergisi, 2(3), 1-27.

Finn, K. E.,\& McInnis, K. J. (2014). Teachers' and students' perceptions of the active science curriculum: Incorporating physical activity into middle school science classrooms. Physical Educator, 71(2), 234.

Gilbert, J. K. (2004). Models and modelling: Routes to more authentic science education. International Journal of Science and mathematics Education, 2(2), 115-130. doi: 10.1007/s10763-004-3186-4

Halloun, I. (2004a). Modeling theory for paradigmatic evolution. Proceedings of the 12th Annual Meeting of the Southern African Association for Research in Mathematics, Science and Technology Education. Cape Town: SAARMSTE.

Halloun, I. (2004b). Mediated modeling for meaningful learning of science. Proceedings of the 8th Annual Science and Mathematics Teachers Conference. Beirut: SMEC \& UNESCO. 
Halloun, I. A. (2006). Modeling theory in science education. Netherlands: Springer.

Halloun, I. (2007). Mediated modeling in science education. Science \& Education, 16(7), 653-697. doi: 10.1007/s11191-006-9004-3

Halloun, I. A. (2011). Modeling and student learning in science education. In Khine, M. S., \& Saleh, I. M. (Eds.). Models and modeling: Cognitive tools for scientific enquiry (Vol. 6). Springer Science \& Business Media.

Johnson, D. W., Johnson, R. T., \& Holubec, E. J. (1993). Cooperation in the classroom. Edina, Minnesota: Interaction Book Company.

Jones, P. (2007). When a wiki is the way: Exploring the use of a wiki in a constructively aligned learning design. In ICT: Providing choices for learners and learning. Proceedings ascilite Singapore, 2007.

Justi, S. R. \& Gilbert, K. J. (2002). Modelling teachers' views on the nature of modelling and implications for the education of modellers. International Journal of Science Education, 24(4), 369-387. doi: 10.1080/09500690110110142

Köseoğlu, F. \& Tümay, H. (2013). Constructive paradigm in science education is theoretically [Bilim ĕgitiminde yapılandırıcı paradigma teoriden öğretim uygulamalarına]. Ankara: Pegem.

Lehrer, R. \& Schauble, L. (2005). Developing modeling and argument in the elementary grades. Understanding Mathematics and Science Matters, 29-53.

Nelson, P. M., Ysseldyke, J. E., \& Christ, T. J. (2015). Student perceptions of the classroom environment actionable feedback to guide core instruction. Assessment for Effective Intervention, 41, 16 -27. http://dx.doi.org/10.1177/15345084 15581366

Nunez-Oviedo, M. C. (2004). Teacher-student co-construction process in Biology: Strategies for developing mental models in large group discussions. Unpublished Doctoral Dissertation, Universtiy of Masachusetts Graduat School, Amherst.

Odubunni, O. \& Balagun, T. A. (1991). The effects of laboratory and lecture teaching methods on cognitive achievement in integrated science. Journal of Research in Science Teaching, 28, 213-224.

Oliva, J. M., del Mar Aragón, M., \& Cuesta, J. (2014). The competence of modelling in learning chemical change: a study with secondary school students. International Journal of Science and Mathematics Education, 13(4), 751-791. doi: 10.1007/s10763-014-9583-4

Pallant, J. (2013). SPSS survival manual. McGraw-Hill Education (UK).

Prensky, M. (2008). Students as designers and creators of educational computer games: Who else? British Journal of Educational Technology,39(6), 1004-1019. doi: 10.1111/j.1467-8535.2008.00823_2.x

Satchwell, R. E. (1996). Using functional flow diagrams to enhance technical systems understanding. Journal of Industrial Teacher Education, 34(2), 50-81. 
Schmidt, H. J. (1997). Students' misconceptions-looking for a pattern. Science education, 81(2), 123-135. doi: 10.1002/(SICI)1098-237X (199704)81:2<123: AIDSCE1>3.0.CO;2-H

Schunk, D. H. (2011). Öğrenme teorileri, eğitimsel bir bakışla (2.Basım) (Trans. M. Sahin). Ankara: Nobel.

Schwarz, C. V. \& White, B. Y. (2005). Metamodeling knowledge: Developing students' understanding of scientific modeling. Cognition and instruction, 23(2), 165-205. doi: $10.1207 /$ s1532690xci2302_1

Seel, N. M. (2001). Epistemology, situated cognition and mental models: Like a bridge over troubled water. Instructional Science, 29, 403-427. doi: 10.1023/A:1011952010705

Sezek, F., Zorlu, Y., \& Zorlu, F. (2015). Examination of the factors influencing the scientific process skills of the students in the elementary education department. Journal of Education Faculty, 17(1), 197-217. doi: 10.17556/jef.38139

Souvignier, E. \& Kronenberger, J. (2007). Cooperative learning in third graders' Jigsaw groups for mathematics and science with and without questioning training. British Journal of Educational Psychology, 77, 755-771.

Tenenbaum, G., Naidu, S., Jegede, O., \& Austin, J. (2001). Constructivist pedagogy in conventional on-campus and distance learning practice: An exploratory investigation. Learning and instruction, 11(2), 87-111. doi: 10.1016/S09594752(00)00017-7

Ünal-Çoban, G., \& Ergin, Ö. (2011). View of the scientific knowledge's existence domain through model based instruction. The Journal of Turkish Educational Sciences, $9(2), 211-254$.

Ünal-Çoban, G. (2009). The effects of model based science education on students? conceptual understanding, science process skills, understanding of scientific knowledge and its domain of existence: The sample of $7^{\text {th }}$ grade unit of light. Unpublished Doctoral Dissertation. Dokuz Eylül University.

Ural-Keleș, P. (2009). Determining effectiveness of guided materials based on the 5e model enriched with conceptual change texts, games and drama students: A sample of classification of living things. Unpublished Doctoral Dissertation. Karadeniz Teknik University.

Wilkinson, S. (2004). Focus group research. In D. Silverman (Edt.) Qualitive research: Theory, method and practice. London: Sage.

Windschitl, P. D., Rose, J. P., Stalkfleet, M. T., \& Smith, A. R. (2008). Are people excessive or judicious in their egocentrism? A modeling approach to understanding bias and accuracy in people's optimism. Journal of Personality and Social Psychology, 95(2), 253. doi: 10.1037/0022-3514.95.2.253 
Wolf, S. J., \& Fraser, B. J. (2008). Learning environment, attitudes and achievement among middle-school science students using inquiry-based laboratory activities. Research in science education, 38(3), 321-341.

Yang, K. K., Lee, L., Hong, Z. R., \& Lin, H. S. (2016). Investigation of effective strategies for developing creative science thinking. International Journal of Science Education, 38(13), 2133-2151. doi: 10.1080/09500693.2016.1230685

Yıldırım, A., \& Şimşek, H. (2005). Qualitative research methods in the social sciences [Sosyal bilimlerde nitel araştırma yöntemleri]. Ankara: Seçkin.

Zorlu, F. (2016). Effects of activities based on modeling learning method and cooperative learning model of students in elementary science and technology course. Unpublished Doctoral Dissertation. Atatürk University.

Zorlu, F., \& Sezek, F. (2019).Students' Opinions about the Effect of the Application of Learning Together and Group Investigation Methods at Different Intervals on the Features of Cooperative Learning Model. Malaysian Online Journal of Educational Sciences, 7(2), 10-24.

Zorlu, Y., \& Zorlu, F. (2015). Views of teachers and levels of students on the learning environment in science and technology course. Route Educational and Social Science Journal, 2(1), 103-114. doi: 10.17121/ressjournal.215

Zorlu, F., Zorlu, Y., Sezek, F., \& Akkuş, H. (2014). Secondary eighth graders' the scores of scientific process skills and their relationship with the scores of their placement test results, Journal of Ekev Academy, 18(59), 519-532. 